\title{
Meningkatkan Keterampilan Sosial Siswa dengan Menerapkan Model Pembelajaran Berbasis Masalah
}

\author{
Putu Agus Gunawan*1, Luh Indrayani ${ }^{2}$ \\ 1,2Program Studi Pendidikan Ekonomi \\ Universitas Pendidikan Ganesha \\ Singaraja, Indonesia
}

e-mail: putuagusgunawan2020@gmail.com¹, luhindrayani25@gmail.com²

Pengutipan: Gunawan, P. A. Indrayani, Luh. (2021). Meningkatkan Keterampilan Sosial Siswa dengan Menerapkan Pembelajaran Berbasis Masalah. Jurnal Pendidikan Ekonomi Undiksha, 13(1), 44-49 http://dx.doi.org 110.23887/jipe.v $\underline{13 i 1.32090}$

\begin{abstract}
Abstrak
Riwayat Artikel

Tanggal diajukan:

11 Februari 2021

Tanggal diterima : 4 Mei 2021

Tanggal dipublikasikan: 25 Juni 2021

Kajian ini bertujuan untuk melihat peningkatan keterampilan sosial siswa kelas 8 B3 SMPN 4 Singaraja memakai model pembelajaran berbasis masalah pada pembelajaran IPS. Penelitian ini dilakukan di SMPN 4 Singaraja, dengan menggunakan subjek siswa kelas 8 B3 sebanyak 36 siswa. Objek pada penelitian ini adalah keterampilan sosial siswa. Pendekatan yang digunakan pada penelitian ini adalah pendekatan kuantitatif. Pengumpulan data menggunakan kuisioner dan wawancara, dengan instrumen kisi-kisi instrumen keterampilan sosial dan lembar wawancara. Dari hasil analisis data, penerapan model Pembelajaran Berbasis Masalah pada pembelajaran IImu Pengetahuan Sosial dapat meningkatkan keterampilan sosial siswa kelas 8 B3 SMPN 4 Singaraja. Pernyataan tersebut dapat dibuktikan dengan hasil penelitian yang menunjukan bahwa rata-rata skor keterampilan sosial siswa kelas 8 B3 sebesar $76 \%$. Pencapaian ini mengalami peningkatan sebesar $12 \%$ dengan kondisi awal sebesar $64 \%$. Rata-rata skor keterampilan sosial siswa kelas $8 \mathrm{~B} 3$ sebesar $84 \%$. Pencapaian ini mengalami peningkatan sebesar $8 \%$ dengan kondisi awal sebesar $76 \%$.
\end{abstract}

Kata Kunci: ilmu pengetahuan sosial; pembelajaran berbasis masalah; keterampilan sosial.

\begin{abstract}
This study aims to see the improvement of social skills of 8 B3 grade students of SMPN 4 Singaraja using a problem-based learning model in social studies learning. This research was conducted at SMPN 4 Singaraja, using 36 students as the subject of grade 8B3. The object of this research is the students' social skills. The approach used in this research is a quantitative approach. Data collection used questionnaires and interviews, with social skills instruments grid instruments and interview sheets. From the results of data analysis, the application of the Problem Based Learning model in Social Sciences learning can improve the social skills of grade 8 B3 students of SMPN 4 Singaraja. This statement can be proven by the results of the study which showed that the average score of social skills of grade 8 B3 students was $76 \%$. This achievement has increased by $12 \%$ with the initial condition of $64 \%$. The average score of students' social skills in class $8 \mathrm{~B} 3$ was $84 \%$. This achievement has increased by $8 \%$ with the initial condition of $76 \%$.
\end{abstract}

Keywords: social science; problem based learning; social skills.

\section{PENDAHULUAN}

Perubahan yang mendasar terjadi pada pendidikan di Indonesia. Perubahan tersebut terutama yang berkaitan dengan undang-undang tentang sistem pendidikan
Berbagai macam perubahan sistem pendidikan terutama bagian manajemen dan kurikulum serta perubahan teknis lainnya dengan harapan bisa memberikan solusi terhadap problematika pendidikan. 
Pendidikan di Indonesia mengalami permasalahan terhadap kapasitas daya serap siswa yang sangat rendah sehingga mempengaruhi kualitas pendidikan.

Upaya dalam pencapaian tujuan pendidikan nasional sudah dilakukan oleh pemerintah terutama dalam meningkatkan kualitas pendidikan seperti, meningkatkan anggaran pendidikan, mengembangkan kurikulum, penerapan metode pembelajaran yang inovatif dan memberikan pelatihan kepada guru. Semua itu ditujukan untuk memperbaiki dan meningatkan hasil berlajar dan keterampilan siswa.

Cara meningkatkan keterampilan sosial siswa salah satunya adalah mempelajari IImu Pengetahuan Sosial. Peningkatan keterampilan sosial sangat penting dalam mencapai tujuan pendidikan nasional. IImu Pengetahuan Sosial bertujuan untuk meningkatkan kesadaran siswa dengan nilai-nilai sosial dan bisa diterapkan dalam kehidupan bermasyarakat. Keterampilan sosial semestinya selalu diasah agar siswa memiliki kemampuan dalam memecahkan masalah. Namun kenyataannya, tujuan dari keterampilan sosial belum bisa dicapai dari pembelajaran IPS.

Berdasarkan hasil observasi awal pada kelas 8 B3 di SMP $\quad \mathrm{N} \quad 4$ Singaraja didapatkan permasalahan bahwa pembelajaran IPS belum bisa meningkatkan keterampilan sosial siswa. Hal itu dapat dilihat dari kurang aktifnya peserta didik di dalam kelas, belum mampu mengemukakan pendapat/ pertanyaan dan belum ada timbal balik siswa kepada guru di dalam proses belajar mengajar. Penyebab siswa masih pasif di kelas adalah guru belum melibatkan siswa dan siswa belum menjadi pusat dari pembelajaran. Guru masih menjadi titik fokus di kelas sehingga guru lebih mendominasi dibandingkan siswa. Guru bertugas dan bertanggungjawab kepada yang membutuhkan ilmu dan seni mengajar adalah menciptakan suasana pembelajaran yang interaktif agar siswa dapat berinteraksi dengan lingkungan secara aktif dan inspiratif agar merangsang siswa belajar untuk memecahkan masalah social yang dihadapi dan dialami (Putu et al., 2018). Dari hasil angket yang diberikan pada tahap pra tindakan, keterampilan sosial siswa kelas 8 B3 masih masuk ke dalam kategori rendah. Pernyataan ini dapat diamati dari jumlah peserta didik, dari 36 orang hanya 9 orang siswa yang memilki keterampilan sosial baik, sebesar 39\% (14 siswa) memiliki keterampilan sosial kurang, dan sebesar $36 \%$ (13 siswa) memiliki keterampilan sosial sangat kurang. Perolehan nilai tersebut menjadi acuan permasalahan bahwa siswa kelas 8 B3 di SMPN 4 Singaraja belum mempunyai keterampilan sosial yang baik. Dari permasalahan tersebut, kajian ini digunakan untuk meningkatkan keterampilan sosial siswa kelas 8 B3 SMPN 4 Singaraja memakai model pembelajaran berbasis masalah.

\section{Teori Belajar}

Pandangan Kontruktivisme, belajar diartikan sebagai proses aktif pembelajaran mengkonstruksi makna melalui tahapan memadukan dan menyatukan antara pengalaman yang dialami dengan materi yang dipelajari (Lasmawan, 2016). Ciri-ciri siswa yang sudah mampu menginterpretasikan pengetahuannya yaitu : (1) siswa mampu menemukan makna dari proses belajarnya; (2) siswa mampu mengkontruksi setiap persoalan yang baru; (3) siswa mampu mengembangkan pemikiran baru dari proses belajarnya; (4) siswa mampu memacu belajarnya ketika mengalami situasi yang tidak seimbang; (5) hasil belajar siswa berasal dari pengalaman belajar (6) apa yang sudah dipelajari akan berdampak pada hasil belajar siswa.

\section{Tinjauan Pembelajaran IPS}

Menurut KTSP dinyatakan bahwa pembelajaran IPS diberikan agar siswa memiliki rasa cinta terhadap bangsa Indonesia, demokratis, dan bertanggungjawab karena IPS mengkaji tentang isu sosial. Pembelajaran IPS memuat ekonomi, geografi, sosiologi, dan sejarah. Menurut Banks sebagaimana dikutip (Lasmawan, 2016) terdapat empat tujuan dari pendidikan IPS yaitu (1) memperluas wawasan ilmu pengetahuan, (2) meningkatkan keterampilan, (3) membangun sikap dan nilai, dan (4) aksi masyarakat. Kemampuan yang harus 
dimiliki siswa ketika mempelajari IPS adalah mengetahui konsep, berpikir kritis, memiliki kesadaran dengan nilai kemanusiaan, memiliki kemampuan berkomunikasi dan bekerjasama dengan masyarakat, serta mampu bersaing dan berkompetisi di tingkat lokal maupun internasional. Dari beberapa tujuan pembelajaran IPS, intinya adalah pendidikan IPS akan membentuk karakter manusia yang siap berkorban dan terlibat dalam kehidupan sosial, serta menjadi teladan di masyarakat (Lasmawan, 2016). Pembelajaran IPS menekankan pada pola agar siswa tidak hanya menghapal materi tapi mampu memahami yang dipelajari dan bisa menerapkannya di kehidupan bermasyarakat. Sehingga guru harus bisa merancang pembelajaran yang fokus terhadap potensi siswa agar pembelajaran bisa bermanfaat.

\section{Model Pembelajaran Berbasis Masalah}

Raharso (2007) berpendapat bahwa pembelajaran berbasis masalah bisa membuat siswa belajar tanpa guru, yang artinya model pembelajaran ini lebih menekankan untuk belajar sendiri secara langsung. Menurut Dewey (dalam Abidin, 2014) model pembelajaran berbasis masalah bersumber dari cara guru menarik siswa untuk menyelidiki dan menciptakan sesuatu. Guru menggunakan cara yang efektif untuk bisa menarik minat siswa agar memiliki keterampilan belajar. Pembelajaran harus bisa dikaitkan dengan kehidupan sehari-hari siswa sehingga secara alami akan menuntun siswa untuk berpikir cara memecahkan masalah yang memiliki makna, kontekstual, dan relevan. Hal ini juga didukung oleh Margetson yang mengemukakan bahwa siswa dituntun untuk aktif, memiliki pola pikir yang kritis, terbuka terhadap wawasan pengetahuan untuk meningkatkan keterampilan belajarnya. Kurikulum pembelajaran berbasis masalah sudah mengatur sistem agar menunjang siswa untuk berhasil memecahkan masalah bisa berkomunikasi dengan baik, mampu bekerja kelompok, dan bisa meningkatkan kemampuan interpersonal.

Karakteristik dari model pembelajaran berbasis masalah yaitu (1) memberikan kesempatan siswa untuk mengajukan pertanyaan atau membahas suatu permasalahan. Model pembelajaran ini dirancang untuk membahas permasalahan berupa permasalahan yang terjadi di kehidupan yang berkaitan dengan pembelajaran, dan berusaha untuk mendapatkan makna serta solusi terhadap permasalahan tersebut. (2) Memiliki titik fokus terhadap keterkaitan antar disiplin ilmu. (3) Merancang suatu penyelidikan secara autentik dalam menyelesaikan permasalahan. Adapun langkah-langkah dalam melakukan penyelidikan yaitu memberikan analisis dan mengartikan masalah, merumuskan hipotesis, mengumpulkan informasi dan menganalisisnya, melakukan uji coba, dan menarik kesimpulan terhadap permasalahan yang dibahas. (4) Mampu menciptakan suatu karya/ produk yang bisa menjelaskan cara penyelesaian masalah yang siswa (5) membentuk kelompok (4-8 orang) dalam menyelesaikan masalah yang dihadapi sehingga dapat memupuk kerja sama.

Model pembelajaran berbasis masalah menjadi salah satu cara yang digunakan untuk meningkatkan kualitas pembelajaran. Langkah-langkah untuk menerapkan model pembelajaran ini adalah pemberian kesempatan kepada siswa untuk menemukan sendiri pembelajaran melalui proses mengamati objek, meneliti, dan menginterogasi hal-hal yang memiliki keterkaitan dengan materi pelajaran yang dipelajari. Dari proses tersebut, siswa bisa mengetahui materi karena mengalaminya sendiri. Persiapan yang diperlukan harus matang bagi oleh guru maupun siswa. Guru harus bisa memberikan siswa kebebasan agar siswa bisa memiliki pikiran yang tajam untuk menyelesaikan permasalahan. Model pembelajaran ini berguna untuk meningkatkan tanggungjawab siswa terhadap pekerjaannya, meningkatkan kemampuan intelektual siswa, meningkatkan semangat dalam mengikuti pembelajaran, dan meningkatkan kemampuan untuk menyelesaikan suatu permasalahan. Keberhasilan dari pelaksanaan model ini tergantung dari motivasi dan interprestasi yang diberikan oleh pihak guru. Siswa harus dituntun 
langkah per langkah yaitu memiliki pikiran yang intelektual, paham terhadap konsep dan menemukan potensi akademiknya.

\section{METODE}

Kajian ini menggunakan pendekatan kuantitatif yang dilakukan di SMPN 4 Singaraja. Adapun yang menjadi subyek dalam kajian ini adalah siswa kelas 8 B3 yaitu sebanyak 34 siswa, dengan jumlah siswa perempuan sebanyak 16 orang, dan siswa laki-laki sebanyak 18 orang. Dalam mengumpulkan data, penelitian ini menggunakan angket dan wawancara dengan objeknya adalah keterampilan sosial siswa kelas 8 B3 SMPN 4 Singaraja. Angket berfungsi sebagai instrumen yang digunakan peneliti dalam mengukur tingkat keterampilan sosial siswa di setiap siklusnya. Guru IPS kelas 8B3 akan menjadi informan untuk wawancara yang akan diadakan setiap akhir siklus. Instrumen yang digunakan dalam mengumpulkan data adalah kisi-kisi instrumen keterampilan sosial dan lembar wawancara. Aspek-aspek yang diukur dalam kisi-kisi instrumen keterampilan sosial dituangkan berupa pertanyaan atau pernyataan yang dijawab responden. Terdapat 25 item pertanyaan di dalam kuisioner yang berhasil disusun untuk mengukur keterampilan sosial siswa. Pertanyaan ini akan dijawab memakai model skala likert yang terdiri dari lima alternatif jawaban. Peneliti mendeskripsikan hasil wawancara dengan guru. Sebelum instrumen diberikan kepada respondes, peneliti melakukan uji coba terlebih dahulu dengan tujuan untuk memperjelas maksud dari pertanyaan, meminimalkan kata yang sulit dimengerti, dan untuk mengurangi atau menambah item pertanyaan. Instrumen diuji coba untuk dilihat validitas dan reliabilitas instrumen. Dengan demikian dapat diketahui instrumen tersebut layak atau tidak dipakai untuk mengambil data penelitian. Cara menganalisis data dalam penelitian ini adalah menggunakan analisis deskriptif kualitatif dan analisis deskripstif kuantitatif. Adapun langkah-langkahnya menurut Sudjana (2009) yaitu:

1. Menghitung nilai maksimal dari tes yang diberikan.

2. Nilai yang didapat siswa dijumlahkan.
3. Didapatkan skor keterampilan sosial siswa.

4. Cara menghitung skor pencapaian keterampilan siswa dengan menggunakan rumus:

Skor siswa $=\frac{\text { skor yang diperoleh siswa }}{\text { skor maksimum semua aspek }} \times 100 \%$

Setelah menemukan skor siswa, maka langkah selanjutnya adalah mencari ratarata dari keterampilan sosial siswa dengan rumus :

$$
\mathrm{Mx}:=\frac{\sum x}{N}
$$

Ket:

$\mathrm{Mx}=$ rata - rata

$\sum x=$ total nilai siswa keseluruhan

$N=$ kuantitas siswa

Jika rata -rata nilai berada rentangan 86 -100 maka masuk dalam kategori baik sekali; rentangan 76 -85 masuk ke dalam kategori baik; rentangan 60 -75 masuk ke dalam kategori cukup; rentangan 55 -59 masuk ke dalam kategori kurang; dan rentangan $<54$ masuk ke dalam kategori kurang sekali.

Presentase siswa pada masing-masing kategori dihitung dengan rumus (Sudjana, 2009: 103):

\section{$\frac{\text { Jumlah siswa yang mencapai kategori yang dicari }}{\text { skor maksimum semua aspek }} \times 100 \%$}

Kriteria Keberhasilan Tindakan

Jika $>80 \%$ siswa di kelas 8 B3 SMPN 4 Singaraja mendapatkan nilai keterampilan sosial > 76 (berada kategori baik), maka penelitian tindakan ini dinyatakan berhasil.

\section{HASIL DAN PEMBAHASAN}

Hasil Penelitian

Hasil angket yang diberikan kepada siswa kelas 8 B3 pada tahap pra tindakan yang dilakukan pada tanggal 8 November 2020 menunjukan bahwa tingkat keterampilan sosial siswa masih rendah. Adapun rincian dari hasil angket pada pratindakan yaitu: persentase siswa yang tergolong keterampilan sosial sangat baik 
$0 \%$, persentase siswa yang tergolong keterampilan sosial baik sebesar $14 \%$, siswa yang mendapatkan kategori cukup sebesar $56 \%$, siswa yang mendapatkan kategori kurang sebesar $25 \%$, dan $5 \%$ siswa mendapatkan kategori sangat kurang. Untuk menghitung skor keterampilan sosial siswa kelas 8 B3 dengan mencari rata-rata keterampilan sosial semua siswa. Dari angket yang sudah diisi siswa pada tahap pratindakan diperoleh rata-rata sebesar $64 \%$. Angka ini masuk ke dalam kategori cukup.

Pada tiga kali pertemuan di tahap awal dilakukan tindakan siklus I, yaitu pada tanggal 15 Oktober 2020, 22 Oktober 2020, dan 24 Oktober 2020. Keterampilan sosial siswa diukur menggunakan angket kuesioner yang diberikan setelah tindakan. Tujuan dari pemberian angket ini dimaksudkan untuk mengetahui sejauh mana keterampilan sosial siswa setelah dilakukan tindakan. Adapun rincian data yang diperoleh pada siklus 1 , yaitu: siswa yang masuk ke dalam kategori sangat baik sebesar $25 \%$. Hal ini meningkat sebesar $25 \%$ dari kondisi awal sebesar 0\%. Siswa yang masuk kategori baik sebesar $25 \%$. Kategori baik mengalami kenaikan sebesar 9\% dari kondisi awal sebesar 14\%. Siswa yang masuk kategori cukup sebesar $44 \%$. Kategori cukup mengalami penurunan sebesar $12 \%$ dari kondisi awal sebesar $56 \%$. Siswa yang masuk kategori kurang sebesar 3\%. Kategori kurang mengalami penurunan sebesar $22 \%$ dari kondisi awal sebesar $25 \%$. Rata-rata skor keterampilan sosial siswa kelas 8 B3 sebesar $76 \%$. Pencapaian ini mengalami peningkatan sebesar $12 \%$ dengan kondisi awal sebesar $64 \%$.

Pada tiga kali pertemuan selanjutnya dilakukan tindakan siklus II dilakukan dalam jenjang waktu tiga kali pertemuan, yaitu pada tanggal 31 Oktober 2020, 05 November 2020, dan 07 November 2020. Siswa yang masuk ke dalam kategori sangat baik sebesar $50 \%$. Hal ini meningkat sebesar $25 \%$ dari kondisi awal sebesar $25 \%$. Siswa yang masuk kategori baik sebesar $42 \%$. Kategori baik mengalami kenaikan sebesar $17 \%$ dari kondisi awal sebesar $25 \%$. Siswa yang masuk kategori cukup sebesar $8 \%$. Kategori cukup mengalami penurunan sebesar $36 \%$ dari kondisi awal sebesar 44\%. Siswa yang masuk kategori kurang sebesar $0 \%$. Ratarata skor keterampilan sosial siswa kelas 8B3 sebesar 84\%. Pencapaian ini mengalami peningkatan sebesar $8 \%$ dengan kondisi awal sebesar $76 \%$.

\section{Pembahasan}

Hasil dari penelitian yang sudah diuraikan menjadi acuan peneliti untuk memperlihatkan bahwa model pembelajaran berbasis masalah dapat meningkatkan keterampilan sosial siswa kelas 8 B3 SMPN 4 Singaraja. Siswa belum mampu berpatisipasi dalam proses pembelajaran pada tahapan pra tindakan. Siswa tidak terlibat secara aktif di kelas dan hanya mengandalkan guru untuk memberikan materi. Pada tahap pratindakan, siswa masih pasif serta belum mampu berbaur dengan teman-teman yang berbeda. Siswa juga tidak menghargai pendapat temannya dan belum bisa bekerjasama dengan temannya. Setelah model pembelajaran kooperatif tipe PBL diterapkan pada siklus I, keterampilan sosial siswa mengalami kenaikan. Siswa mulai mampu mengemukakan pendapatnya dan mampu menghargai pendapat temannya. Siswa juga terlihat aktif berkomunikasi dan mulai menjalin kerjasama secara kompak di dalam kelompoknya. Keterampilan sosial siswa pada siklus II mengalami kenaikan dari siklus I. Peneliti membagi siswa ke dalam beberapa kelompok yang bersifat plural. Selain itu, siswa juga diberikan arahan agar saling bekerja sama, berinteraksi, berkomunikasi dengan baik dan memiliki rasa tanggung jawab. Penerapan model pembelajaran berbasis masalah pada saat peneliti melakukan penelitian terlihat siswa lebih aktif bertanya maupun lebih aktif menjawab pada saat diskusi, siswa juga mampu untuk saling berinteraksi, berkomunikasi serta bekerja sama dengan teman dalam kelompok. Hasil penelitian ini juga didukung oleh penelitian dari (Huang \& Wang, 2012) yang menunjukan bahwa siswa termotivasi dan terinspirasi oleh belajar dengan cara yang kolektif dan kooperatif, serta mengembangkan ikatan persahabatan yang berharga. Penelitian 
Dewi et al. (2014) yang menyatakan bahwa hasil belajar siswa dengan menggunakan model pembelajaran berbasis masalah mendapatkan nilai yang lebih tinggi dibandingkan dengan hasil belajar siswa yang menggunakan model pembelajaran yang konvesional. Penelitian ini diperkuat oleh kajian dari (Suardani \& Swasta, 2006) yang juga membandingkan hasil belajar siswa yang menggunakan model pembelajaran berbasis masalah dengan model pembelajaran konvesional. Kajian dari (Murwantono, 2015) menyatakan bahwa aktivitas belajar siswa dan kualitas pembelajaran IPS mengalami peningkatan ketika diterapkannya model pembelajaran berbasis masalah.

\section{SIMPULAN DAN SARAN}

Simpulan

Hasil kajian dan pembahasan yang telah dijelaskan menarik kesimpulan bahwa keterampilan sosial siswa kelas 8B3 SMPN 4 Singaraja dapat ditingkatkan melalui mata pelajaran IPS dengan memakai model pembelajaran berbasis masalah. Pernyataan ini dapat diamati pada rata-rata skor keterampilan sosial siswa kelas 8B3 sebesar $84 \%$. Pencapaian ini mengalami peningkatan sebesar $8 \%$ dengan kondisi awal sebesar $76 \%$.

Selain dari hasil angket pada tahap pra tindakan dan tahap I, peningkatan keterampilan sosial pada pembelajaran IPS setelah menggunakan model pembelajaran berbasis masalah, dapat dilihat pada angket siklus II. Rata-rata skor keterampilan sosial siswa 8B3 sebesar 84\%. Angka ini mengalami kenaikan sebesar $8 \%$ dari siklus I sebesar $76 \%$. Peningkatan keterampilan sosial siswa kelas 8 B3 SMP N 4 Singaraja pada siklus II memperoleh angka $84 \%$ dari jumlah siswa dan masuk ke dalam kategori baik.

Saran

Saran yang diberikan untuk guru IPS SMP bisa menggunakan model pembelajaran berbasis masalah sebagai solusi dalam meningkatkan keaktifan siswa dan keterampilan sosial siswa. Untuk siswa sebaiknya mulai membuka diri dengan lingkungan dan bisa berbaur dengan sesama teman dan lebih aktif di kelas. Saran untuk peneliti selanjutnya adalah mampu mengembangkan lagi model pembelajaran berbasis masalah tetapi dengan pembelajaran yang berbeda dan lebih meningkatkan keterampilan sosial siswa.

\section{DAFTAR PUSTAKA}

Abidin, Y. (2014). Desain Sistem Pembelajaran Dalam Konteks Kurikulum 2013. Bandung: Refika Aditama.

Dewi, I. A. S. K., Kristiantari, M. . R., \& Putra, M. (2014). Pengaruh Model Pembelajaran Problem Based Learning Berbasis Hypnoteaching Terhadap Hasil Belajar Matematika Siswa Kelas V SD. Jurnal Mimbar PGSD Universitas Pendidikan Ganesha.

Huang, K., \& Wang, T. (2012). Applying Problem-based Learning (PBL) In University English Translation Classe. The Journal of International Management Studies, 7(1), 121-127.

Lasmawan, I. W. (2016). Pendidikan IPS.Singaraja: Undiksha Press.

Murwantono, S. (2015). Peningkatan Hasil Belajar IPS Dengan Model Problem Based Learning Berbantuan Media Stimulan Gambar. Jurnal Pendidikan IPS, 2(1).

Putu, N., Dian, O., Sriartha, I. P., \& Haris, I. A. (2018). Pemecahan Masalah Siswa Pada Pembelajaran Ips Di Smp Negeri 5 Tabanan. Ekuitas: Jurnal Pendidikan Ekonomi, 6(1), 34-41.

Raharso, S. (2007). Implementasi Problem Based Learning di Perguruan Tinggi. Jurnal Kajian Teori Dan Praktek Kependidikan, 34(1), 55-62.

Suardani, N., \& Swasta, M. (2006). Pengaruh Model Pembelajaran Berbasis Masalah Terhadap Kemampuan Pemecahan Masalah Dan Keterampilan Proses Sains Siswa. Jurnal Pendidikan Dan Pembelajaran IPA Indonesia, 4(1).

Sudjana, N. (2009). Penilaian Hasil Proses Belajar Mengajar. Bandung: PT. Remaja Rosdakarya. 